\title{
EL RETABLO DEL SALVADOR DEL MUSEO DE BELLAS ARTES DE SEVILLA
}

\author{
ALFONSO BLANCO LÓPEZ DE LERMA \\ Museo de Bellas Artes de Sevilla (España)
}

Fecha de recepción: 17/09/2021

Fecha de aceptación: 13/11/2021

\begin{abstract}
Resumen
El Retablo del Salvador es una de las obras que se conserva en el Museo de Bellas Artes de Sevilla procedente de la Desamortización de Mendizábal. Pintado al óleo sobre tabla, se puede observar en él ocho escenas diferentes, mostrando la central a Cristo Resucitado que presenta a los redimidos del infierno a su Madre e inspira el título del retablo. Esta escena de Jesús tras bajar al Seno de Abraham, cuya datación es cercana a la mitad del siglo XVI, está inspirada en una obra de la antigua colección Parcent. Chandler Rathfon Post en su $A$ History of Spanish Painting la relaciona con un San Telmo que también se encuentra en el Museo sevillano. ${ }^{1}$
\end{abstract}

Palabras clave

Retablo; tabla; anónimo; colección Parcent; Alejo Fernández.

\section{THE SAVIOUR ALTARPIERCE FROM THE MUSEUM OF FINE ARTS OF SEVILLE}

\begin{abstract}
Summary
The altarpiece of the Saviour is one of the works preserved in the Fine Arts Museum of Seville, coming from the Spanish confiscation of assets carried out by Mendizábal. Oil-painted on panel, it shows eight different scenes. The central one shows the risen Christ, redeemed from hell and delivered to his Mother, which inspires the title of the altarpiece. This scene of Jesus, after descent into Abraham's Bosom, which dates towards the middle of the sixteenth century, is inspired by a work from the old Parcent collection. Chandler Rathfon Post in his A History of Spanish Painting relates it to a Saint Telmo that is also found in the Sevillian Museum.
\end{abstract}

Key words

Altarpierce; panel; anonymous; Parcent collection; Alejo Fernandez.

\footnotetext{
${ }^{1}$ Agradezco la ayuda en la realización de este artículo: Fuensanta García, Teresa Laguna, Juan Manuel Villanueva, Carmen Lozano, María José Blanco, David Glyn, Rocío Campos, María José Robina; Roberto Alonso, FOCUS, Sotheby's Madrid, Marta Torres, María Teresa Rodríguez, Biblioteca Histórica de la Universidad Complutense de Madrid, Miguel Domínguez y Fuensanta de la Paz, Ignacio Hermoso, Rocío Izquierdo y todo el equipo técnico del Museo de Bellas Artes de Sevilla.
} 
En el Museo de Bellas Artes de Sevilla se conserva el Retablo del Salvador (fig. 1) del segundo cuarto del siglo XVI, ${ }^{2}$ que llegó al mismo procedente de la Desamortización eclesiástica de Mendizábal (1836). Se ignora su procedencia, pero seguramente estaba en Sevilla debido al origen de las colecciones fundacionales.

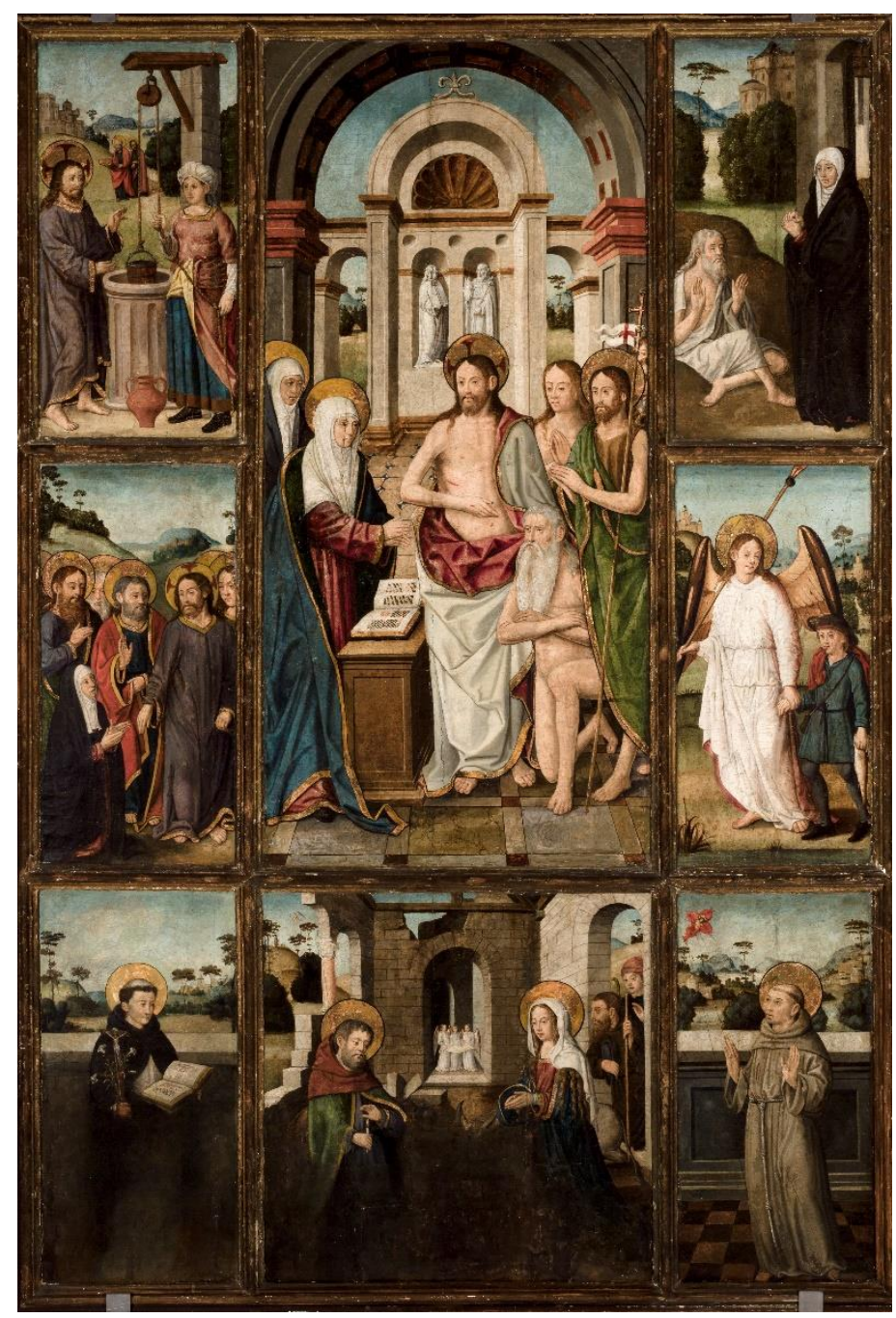

Fig. 1. Anónimo, Retablo del Salvador, mediados del siglo XVI, Museo de Bellas Artes de Sevilla (No $\mathrm{R}^{\circ}$ CE0032P).

Es más que posible que perteneciera a un convento franciscano atendiendo a los santos representados en la parte inferior, Santo Domingo y San Francisco, y su ubicación en la obra; al situar a la derecha del espectador la imagen del de Asís, los frailes franciscanos ceden el lugar de privilegio a Santo Domingo. Del mismo modo, en los retablos de las iglesias dominicas localizamos la imagen de San Francisco a nuestra izquierda.

\footnotetext{
${ }^{2}$ Museo de Bellas Artes de Sevilla. Número de Registro: CE0032P.
} 
Ponz no cita esta pintura en su Viaje de España ${ }^{3}$ (18 volúmenes editados por primera vez entre 17721794), ni tampoco aparece entre las casi mil pinturas recogidas en el Real Alcázar de Sevilla por los franceses durante la ocupación, enumeradas en la publicación de Gómez Imaz. ${ }^{4}$ Se comprende por la relativa importancia del Retablo del Salvador que no haya constancia de él. Se encuentra en el inventario del Museo de 1845 con el número 568 y el título: Un devocionario de la pasión dividido en ocho cuadros. Siendo una fotografía del archivo Ruiz Vernacci ${ }^{5}$ de hacia 1900-1915 (fig. 2) el documento gráfico más antiguo que se conserva.

El Retablo del Salvador lo forman ocho escenas repartidas en tres cuerpos y tres calles, separadas por un fino enmarcado y realizadas en un mismo soporte, cuya distribución es la siguiente: en el cuerpo inferior, en la calle izquierda, la del Evangelio, está ubicado Santo Domingo de Guzmán con libro, azucenas y crucifijo en las manos, la Natividad en el centro, situada en la tradicional construcción en ruinas, con el

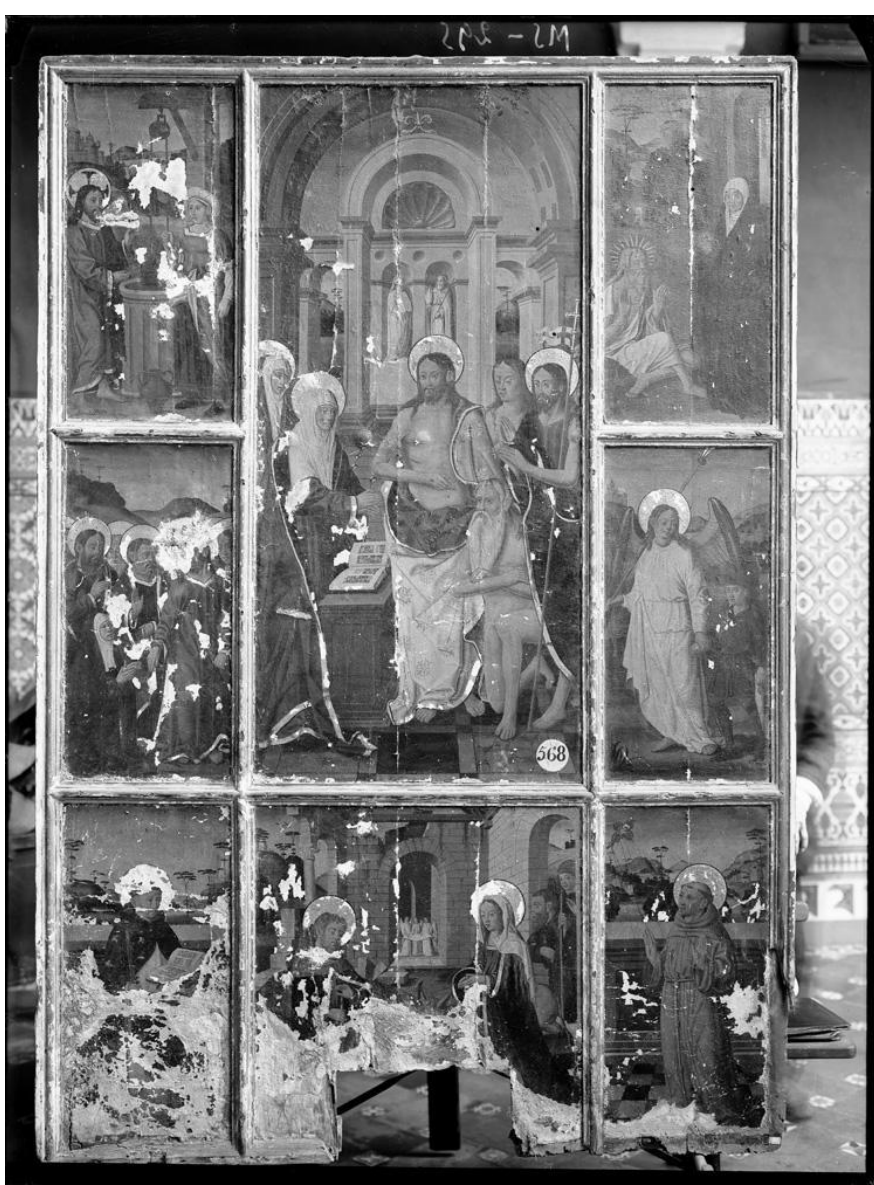

Fig. 2. Anónimo, Retablo del Salvador, mediados del siglo XVI, Museo de Bellas Artes de Sevilla ( ${ }^{\circ} \mathrm{R}^{\circ}$ CE0032P). Archivo Ruiz Vernacci (hacia 1900-1915), ref. VN-28281, Instituto del Patrimonio Cultural de España. Ministerio de Cultura y Deporte. anuncio a los pastores a la izquierda

en el paisaje de fondo (Lucas 2: 7-16) y dos de ellos que se incorporan a la escena por una puerta a la derecha y a su derecha. En la calle de la Epístola San Francisco de Asís recibiendo los estigmas de Cristo Seráfico.

En el cuerpo medio se sitúa una representación de Cristo y los apóstoles con la mujer de Canaán (Mateo 15: 21-28, Marcos 7: 24-30), en la calle central Cristo Resucitado presentando a los redimidos del infierno a su Madre, que es la escena principal y más grande, ocupando los dos cuerpos superiores. La única escena que no aparece en la Biblia es ésta, una imagen de desarrollo posterior que está muy simplificada en el llamado Credo de los Apóstoles (isiglo V?), y que puede tener una cita previa en Hecho de los Apóstoles 2. 31, y explicada en el evangelio apócrifo de Nicodemo sin citar la presencia de María con los redimidos. Posteriormente alguno de los doctores y Padres de la Iglesia incidieron en esta idea. A la

\footnotetext{
${ }^{3}$ Ponz, 1947.

${ }^{4}$ Gómez Imaz, 1917. (Editado por primera vez en 1896)

${ }^{5}$ Archivo Ruiz Vernacci: No Inventario: VN-28281. Retablo con ocho compartimentos. Soporte: Vidrio al gelatino-bromuro, de formato $18 \mathrm{x} 24$. Posiblemente realizada por José Lacoste entre 1900-1915.
} 
derecha de esta escena se sitúa a San Rafael y Tobías (Tobías 6: 3-6).

El cuerpo superior se completa con Cristo con la samaritana en el momento de la llegada de los apóstoles (Juan 4: 27), y a la derecha de la escena central el Santo Job con su mujer (Job 2: 9-10).

\section{Iconografía. Fuentes de inspiración}

El tema que une las diferentes escenas del Retablo del Salvador es la salvación del alma a través de la Fe. ${ }^{6}$

Dos escenas de la calle izquierda representan pasajes recogidos en el Nuevo Testamento: Cristo con la samaritana en el momento de la llegada de los apóstoles y Cristo y los apóstoles con la mujer de Canaán. Se ha apuntado la posibilidad de que sea la mujer hemorroisa, ${ }^{7}$ pero ésta tocó la túnica de Jesús buscando el milagro, y como la que se encuentra en el Retablo lo que hace es rogar a Cristo, quizá sea la cananea. También se ha citado la escena como Cristo apareciéndose a su madre después de la resurrección. ${ }^{8}$ El que este personaje no lleve el halo de santidad nos hace rechazar el que pueda ser la Virgen María.

En la calle derecha las dos escenas son del Antiguo Testamento: El Santo Job ante su mujer (en la Biblia no aparece citado el nombre de ella, aunque la tradición judía apócrifa la nombra como Sitis o Sitidos) y la representación de Tobías y el Ángel. La imagen de San Rafael con Tobías caminando con el pez al borde del río Tigris, no es descrito así en la Biblia; tras la pesca, el arcángel ordena sacarle la hiel, el corazón y el hígado, que es lo único que se cita que portan. Resulta claramente más pictórico el representar un pescado que solamente las vísceras, como se repite en casi todas las obras que los plasman. ${ }^{9}$

En el centro del retablo, y rodeado de las citadas escenas con personajes señalados por su Fe en Dios, está Cristo resucitado, que tras bajar al Infierno de los Justos, o Seno de Abraham, y liberar a Adán, a Eva, a San Juan Bautista (tras él se intuye un par de figuras más como ejemplo de todas las almas que esperaban la redención que trajo el sacrificio del Hijo de Dios), están siendo presentados a la Virgen María, que deja de atender a su libro de oraciones para escuchar a Jesús. Tras Ella se encuentra una de las santas mujeres. ${ }^{10}$

Santo Domingo de Guzmán y San Francisco de Asís están situados en una galería abierta, ante un pretil de sillares de piedra y sobre un suelo de baldosas en damero sencillo (el de la escena de Santo Domingo está prácticamente perdido), y como en todas las escenas el fondo se completa con un paisaje abierto de amplia perspectiva con lomas, vegetación, y algunos edificios. Todos ellos son paisajes deshabitados, exceptuando el anuncio de los pastores y los apóstoles que se aproximan en la escena de la samaritana. ${ }^{11}$

\footnotetext{
${ }^{6}$ En 1517 Martín Lutero (1483-1546) publica un texto contra las indulgencias, de este texto nos interesa destacar aquí el punto Sola fides, sola scripura. La idea de cómo nos puede salvar la Fe fue uno de los temas de discusión en la guerra de religión en el siglo XVI. La Iglesia en Sevilla no sólo no fue ajena a este problema, si no que el origen del protestantismo en la ciudad llegó de mano del canónigo de la Catedral Juan Gil, llegando en uno de los autos de fe a condenar a los monjes jerónimos de San Isidoro del Campo. Que en esa época de religión convulsa se dedicara un retablo así en un convento franciscano pudiera ser significativo.

${ }^{7}$ La escena protagonizada por la hemorroisa la cita: Gestoso y Pérez, 1912: 108.

${ }^{8}$ La escena citada como Cristo apareciéndose a su madre después de la resurrección lo podemos ver en: Moreno Mendoza/Pareja López/Sanz Serrano/Valdivieso González, 1991: 66.

${ }^{9}$ Las medidas de estas cuatro escenas, con ligeras variantes, es de unos 66'00 x 33'00 cms.

${ }^{10}$ La escena mide unos $138{ }^{\prime} 50$ x 64'00 cms.

${ }^{11}$ La Natividad mide unos 65'00 x 64'00 cms., y las de los santos a ambos lados, 65'00 x 33'00 cms., cada una.
} 
El Retablo del Salvador se ha fechado a principios del siglo del siglo XVI, ${ }^{12}$ aunque quizá haya que situarla cercana a la mitad de la centuria, y se ha señalado la influencia de la obra de Alejo Fernández (1475-1545), pero más en la inspiración de la composición de la escena central que en la estética general de los personajes, tanto de los tipos humanos como del plegado de paños, mucho más relacionados con la manera italiana de representarlos que la inspiración flamenca que podemos ver en Alejo Fernández. No hay relación aparente entre la composición de las escenas secundarias y cualquier otra creación conocida de dicho pintor. A pesar de ese aire italianizante citado, el parecido de tipos físicos, proporciones corporales, agrupación de personajes, halos de santidad superpuestos y halos crucíferos de Cristo, los pliegues o las cenefas en los bordes de los ropajes o los paisajes con edificios de recuerdo retardatario, tienen semejanzas con alguno de los grabados de la Peregrinación a tierra santa de Bernhard von Breydenbach (1440-1497), que se editó en España en 1498, ${ }^{13}$ lo que da un cierto aire tardomedieval al retablo a pesar de la época de su realización.

Si se atiende al hecho de que los maestros Pedro de Campaña (1503-1586) y Hernando de Esturmio (1510-1556) llegan a Sevilla en 1537, con un estilo más avanzado que el tardogótico apreciado en las composiciones de nuestro anónimo autor, posiblemente haya que pensar en los últimos años de la producción de un pintor local con una impronta retardataria.

Alejo Fernández pintó La Duda de santo Tomás, hacia 1530, (Iglesia parroquial de Hinojos, Huelva) con algunos personajes que se asemejan a los nuestros, sobre todo Cristo, y Tomás en el lugar que ocupa aquí María; el gran arco con casetones en perspectiva que enmarca la escena está copiado en el Retablo del Salvador, sustituyendo las columnas por pilastras y reduciendo su profundidad. Masaccio (1401-1428) para su Trinidad (1427-1428) de Santa María Novella de Florencia, utilizó anteriormente idéntico arco con casetones y que se aprecian en la obra de Alejo Fernández. ${ }^{14}$ El hecho de que Vasari (1511-1574) pintara La incredulidad de Santo Tomás (1572) para la Basílica de Santa Croce de Florencia, con una composición muy parecida a la de Alejo Fernández, sobre todo el arco, nos remite a una estampa de inspiración común, y que pudiera ser la de Alberto Durero (1471-1528) con idéntico motivo (1509), de su serie sobre La pequeña Pasión, aunque el arco solamente está iniciado. ${ }^{15}$

La pintura con el mismo tema que sin duda es inspiración definitiva para esta escena central es la Aparición de Cristo a la Virgen con los redimidos del Limbo (fig. 3 y 4) y que perteneció a la antigua colección Parcent de Madrid, desconociendo su localización actual. Esta pintura, de estética muy cercana a Fernández, y que Tormo en 1911 la atribuyó a: "Escuela de los estados de Castilla en el segundo ó tercer decenio del siglo XVI, dudándose entre la toledana,

12 Gestoso y Pérez, 1921: 108-109: “ANÓNIMOS. 295. Retablo con ocho compartimentos. Rétable à huit divisions. E.S. En ellos se representa los siguientes asuntos: á la izquierda, Jesús y la Samaritana, la mujer hemorroisa y Santo Domingo de Guzmán. En el centro, el Salvador, y á su diestra Adán y Eva y el Bautista, y dos figuras de Santas á la siniestra. Fondo arquitectónico caprichoso, y en dos hornacinas Moisés y Aarón. Debajo el Nacimiento de Cristo. A la derecha, un Santo desnudo y de hinojos en el suelo, y tras de él una figura de mujer. San Rafael, y la impresión de las llagas á San Francisco en el tablero de la derecha. Principios del siglo XVI. Alto, 2,10; ancho, 1,49. T."

${ }^{13}$ Von Breydenbach, 1486. (Edición latina, 1486, edición alemana, 1486, edición flamenca, 1488).

${ }^{14}$ No podemos olvidarnos que en 1510 queda instalado en la Capilla de la Virgen de la Antigua de la Catedral sevillana el Sepulcro de Don Diego Hurtado de Mendoza, de Doménico di Alessandro Fancelli (1469-1519) y que incluye un arco sobre columnas y con casetones como el utilizado por Alejo Fernández.

${ }^{15}$ La fuente de inspiración pudo ser también la Pasión de Marcantonio Raimondi (1480-1534), que copia la serie de Durero. 
del tiempo de Juan de Borgoña, ó quizá la sevillana, del tiempo de Jorge Fernández Alemán (?), siendo lo primero más probable. En un informe oficial de hace algunos años, se ha tenido como obra de Alonso Berruguete". ${ }^{16}$ Post la atribuye a Juan de Zamora (hacia 1505-1578) con reservas, ${ }^{17}$ aunque en el pie de foto se omite que se considera atribución y se señala como autor, remarcando que la imagen está sacada del catálogo de Tormo.

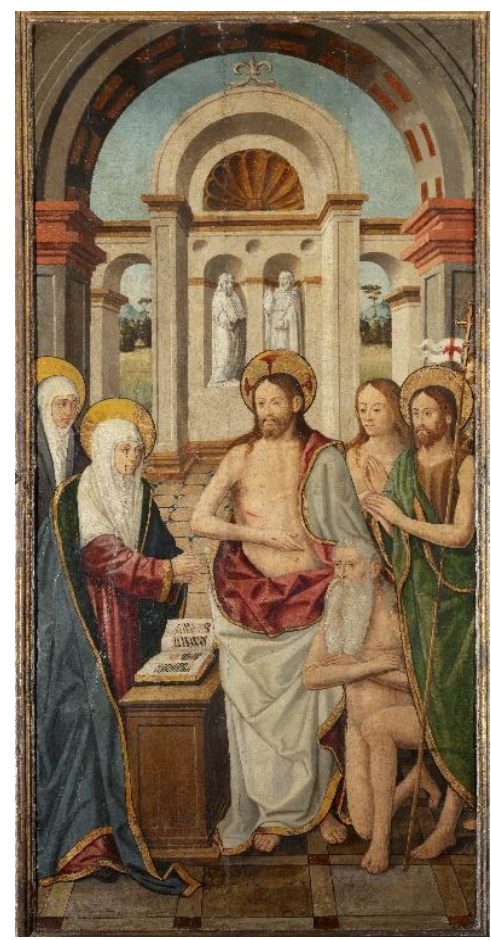

Fig. 3. Anónimo, Retablo del Salvador, mediados del siglo XVI, Museo de Bellas Artes de Sevilla $\left(\mathrm{N}^{\circ}\right.$ $\left.\mathrm{R}^{\circ} \mathrm{CE} 0032 \mathrm{P}\right)$. Detalle con Cristo Resucitado presentando a los redimidos del infierno a su Madre.

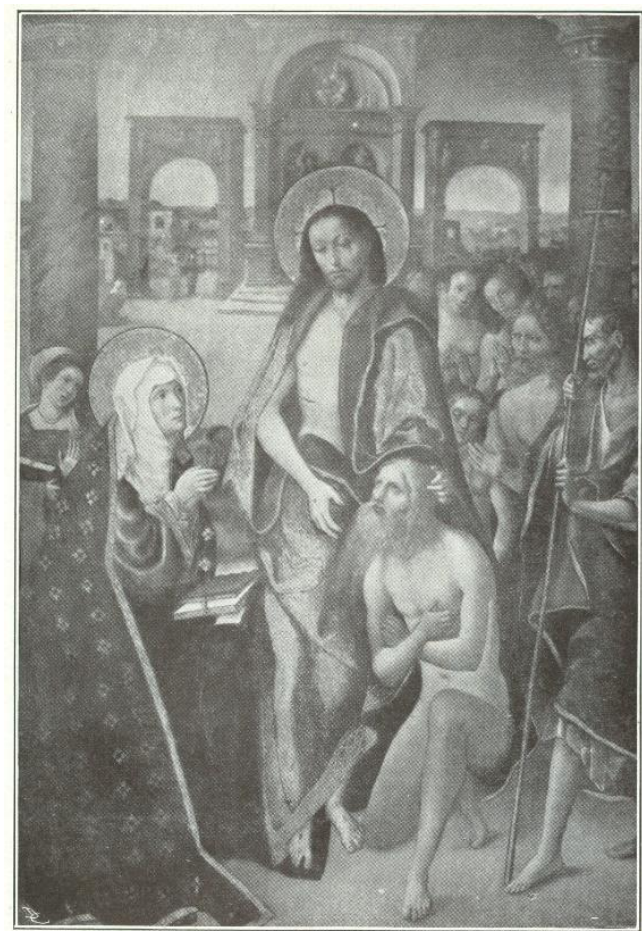

Fig. 4. Alejo Fernández, Aparición de Cristo a la Virgen con los redimidos del Limbo, Hacia 1530, colección privada. Imagen de 1911 publicada en Tormo y Monzó, Elías: Catálogo de las tablas de primitivos españoles de la colección de la Excma. Señora Doña Trinidad Scholtz-Hermensdorff, Viuda de Iturbe. OLegado Alfonso E. Pérez Sánchez. Fundación Fondo de Cultura de Sevilla (Focus), Sevilla.

Esta pintura, que en 1911 se conservaba en la colección de Trinidad ScholtzHermensdorff, del palacio Parcent de Madrid, tras pasar a su heredera se ubica en la finca El Quexigal, propiedad de la princesa de Hohenlohe, siendo subastada con otras de la misma procedencia por Sotheby Parke Bernet \& CO. en 1979. ${ }^{18}$ La Aparición de Cristo a la Virgen con los redimidos del Limbo puede atribuirse a Alejo Fernández dada su calidad y cercanía con otras obras del autor, y no a Juan de Zamora, atribución con la que salió a subasta y que al estudiar

\footnotetext{
16 Tormo y Monzó, 1911: 16.

${ }^{17}$ Post, 1970: 122.

${ }^{18}$ SOTHEBY PARKE BERNET \& CO. SUCURSAL EN ESPAÑA, subasta de 1979, número de lote 46.
} 
la obra de este pintor no se sostiene con demasiado fundamento. ${ }^{19}$

Representa a la Virgen, Cristo, Adán y el Bautista en idéntica ubicación espacial así como parecidas posiciones y vestimentas a la del Retablo del Salvador, que al igual que la del museo sevillano sitúa a media distancia una triple arcada, separados los tres arcos en este caso y algo más monumental y alejada la de Parcent. En la arcada central aparecen nichos y figuras que representan a Moisés y Aarón ${ }^{20}$ como la del museo en la parte media del arco central, y sobre ellos sitúa al Padre Eterno en el lugar donde en nuestro Retablo solamente vemos una venera. Este arco es ciego a modo de retablo en piedra, la representación de Moisés y Aarón es el antecedente bíblico de la salvación del pueblo elegido, al igual que Cristo Resucitado salva a los justos del infierno; tal como Moisés izó la serpiente de bronce para salvar a los pecadores, la Ascensión de Jesús los redimiría, existiendo más asimilaciones con el Salvador del que se considera el primer profeta y legislador de Israel, y Aarón como primer sumo sacerdote de la antigua Ley. En los arcos laterales situó figuras que considero decorativas, pero dada la calidad de la imagen no es posible definirlas, y que no aparecen en el retablo del museo sevillano. La figura femenina arrodillada mirando hacia el arco, que aparece en la tabla Parcent, puede redundar en la idea de retablo, tal como se citó en la subasta de 1979.

La imagen escultórica de Moisés con las tablas de la Ley y su hermano Aarón con la vara y el fuego de las ofrendas en la mano las encontramos también en la tabla asignada al Maestro de Moguer que representa La Última Cena (en paradero desconocido), situadas al fondo de igual manera en un arco y con la venera centrando la composición, está colocada abriéndose de abajo a arriba en la obra del Maestro de Moguer y en la del Retablo del Salvador, encontrándola invertida en la tabla de La Última Cena ( primera década del siglo XVI) de Alejo Fernández, en la Basílica del Pilar de Zaragoza, centrando también el fondo de la composición.

El arco inserto tras la escena que se desarrolla en primer término, a modo de arco de triunfo, y el que la enmarca, pueden aludir a la victoria de Cristo y su Iglesia. Recordemos que los arcos triunfales efímeros erigidos en las ciudades con motivo de diversas celebraciones, religiosas o no, siguen siendo habituales. ${ }^{21}$ El diseño de esta estructura en el Retablo recuerda vagamente un arco serliano, ${ }^{22}$ y sitúa la obra en la Andalucía renacentista de Hernán Ruiz II (1514-1569) o de Andrés de Vandelvira (1505-1575).

En la tabla de la antigua colección Parcent el paisaje del fondo lo ocupa la Jerusalén celeste, las columnas laterales, jaspeadas y con querubines en los capiteles no inician el arco que encontramos en la Incredulidad de santo Tomás de Alejo Fernández, y el suelo es de tierra sin interrupciones hasta la ciudad. La mirada que Cristo dirige a su Madre en la de Parcent, en el Retablo del Salvador significativamente está dirigida al espectador, porque pudiera ser a quien el autor quiere presentar a los rescatados del pecado, no a María, para anunciar lo que alcanzaremos si nos mantenemos en la gracia de Dios. Y por último señalar que la presencia de Eva en el retablo tiene un protagonismo mucho mayor, al lado de San Juan, que obliga a

${ }^{19}$ Gómez Sánchez, 2016: 677-818.

${ }^{20}$ Moisés y Aarón se representan como si fueran esculturas realizadas en piedra blanca insertas en hornacinas.

${ }^{21}$ El autor de la obra aquí estudiada pudo ver los arcos de triunfo, la mayoría de tres vanos, que se erigieron en Sevilla en 1526 por la visita del emperador Carlos con motivo de su boda con Isabel de Portugal, realizados por el arquitecto Diego de Riaño, el escultor Pietro Torrigiano y el pintor Alejo Fernández.

${ }^{22}$ Serlio (1475-1554) publicó sus libros de arquitectura entre 1537 y 1551 . En España se publicaron en Toledo los libros tercero y cuarto en 1552. La ventana serliana fue utilizada por primera vez en Andalucía por Pedro Machuca en el palacio de Carlos V en la Alhambra, iniciado en 1528. 
que el resto de los rescatados apenas sean visibles y se intuyan tras él. Esta representación está sacada de la Creación de Eva, estampa del libro Peregrinación a tierra Santa, ${ }^{23}$ aunque aquí el pecho de Eva está oculto, púdicamente, por la figura del Bautista. María en esta escena se nos presenta como Puerta del Cielo, una de sus definiciones de la Letanía, y como tal está siendo presentada a Adán y sus acompañantes. El hecho de la coincidencia de Eva y la Virgen en la misma escena "se basa en la concepción de María como nueva Eva "reparada" [...] Eva se considera, pues, una prefigura de la Virgen y la idea de la Redención se evoca a través del pecado original". ${ }^{24}$

Los delfines que rematan el arco del fondo, a modo de flor de lis, pudieron ser utilizados como símbolo de la esperanza en la Redención, si pensamos en la meditada simbología usada por los artistas en sus obras.

Comparando las vestimentas de estas dos escenas encontramos significativos cambios de color. Mientras que en la tabla el manto de Cristo es dorado, color de la "Luz de Dios", en el Retablo del Salvador es blanco, utilizado como el color de la "Vida Nueva" que representa el Resucitado, y que lleva unas esquemáticas flores doradas adornándolo; en ambos casos el interior del manto es de color púrpura, al igual que la túnica de la Virgen, color que los emperadores romanos asimilaron al poder supremo y por ello acabó asignándose al Hijo de Dios y a su Madre por relación. María en ambos casos se cubre con un manto azul que redunda en su santidad, y que siendo liso en el Retablo tiene flores doradas en la antigua obra de la colección Parcent. El manto del Bautista en la obra del museo es verde, color de la reconversión espiritual, y rojo en la tabla, posiblemente como símbolo del martirio. ${ }^{25}$

Han de destacarse las vestimentas de otros personajes que aparecen en el Retablo: la esposa de Job, la cananea y la santa mujer que acompaña a la Virgen llevan mantos negros y tocas blancas al igual que las que podemos ver en mujeres del siglo XVI, vestimentas habituales del luto. Casi todas las donantes representadas por pintores como Alejo Fernández, o la que aparece a los pies de las santas sevillanas en la tabla de Santa Justa y Rufina de la parroquia de Santa Ana en Triana visten de la misma manera.

Que el centro de la composición del Retablo, y la más grande, sea la representación del Salvador, que da nombre al conjunto, es de gran importancia desde el punto de vista simbólico, reforzando la importancia de Cristo el que los personajes que lo acompañan estén todos girados hacia él. Tampoco debe ser casual el hecho de que en el centro de la parte inferior tuviera la imagen del Niño Jesús recién nacido y la composición nos lleve de éste al Resucitado. Es posible también que sea premeditado el que las escenas del Antiguo y Nuevo Testamento no tengan una figura centrada en cada composición, estando realizadas claramente sin una perspectiva arquitectónica que dirija nuestra mirada, y así no altere la visión de Cristo como figura clave del Retablo del Salvador.

Post duda cuál de las obras es anterior una a la otra, ${ }^{26}$ la del museo sevillano o la de Parcent. $\mathrm{Al}$ parecerle más torpe la escena del Salvador considera que puede ser inspiración de la que estuvo en la colección madrileña, por otra parte, la calidad superior de ésta hace pensar si un maestro de mayor talento pudo haber copiado a otro inferior a él. Siendo más que probable que la escena central del Retablo del Salvador reproduzca la que atribuimos a Alejo Fernández de la antigua colección Parcent, es lo que retrasaría la fecha de realización de la obra del museo.

\footnotetext{
${ }^{23}$ Von Breydenbach, 1486: XCVII.

24 Ávila, 1993: 69.

${ }^{25}$ La imagen del citado catálogo de la subasta de Sotheby Parke Bernet \& Co. está publicada en color, y es a partir de ésta en la que se basa esta comparación.

${ }^{26}$ Post, 1970: 124.
} 
Pensando que el Retablo del Salvador sea posterior a las dos obras de Alejo Fernández estudiadas, La duda de Santo Tomás y Aparición de Cristo a la Virgen con los redimidos del Limbo, la obra del museo sevillano hubo de ser pintada no antes de mediada la década de los treinta del siglo XVI.

También el resto de las escenas están inspiradas en otras obras, ya sean estampas u otras pinturas conocidas en su época.

La escena de la Natividad copia parcialmente un grabado de Alberto Durero del mismo tema, y que fue impreso en la primera década del siglo XVI. Similares son los pastores que se acercan a adorar al Niño a través de una puerta de medio punto hecha también con sillares de piedra. En el mismo lugar se sitúa la Virgen María, la cercha de la techumbre se asemeja, pero nuestro autor centra la vista del edificio y sitúa el arco del fondo como eje de la composición, y en él coloca los tres ángeles que Durero pone detrás de la cuna del Niño, convirtiéndolos en coro angelical y reduciendo su tamaño. San José con la vela en la mano, muy diferente al de la estampa del pintor alemán, sigue un ejemplo muy repetido en el arte, como refleja la xilografía de hacia 1490 del taller de las pequeñas Horas de Ana de Bretaña, que representa una Natividad, atribuida a Jean d'Ypres (14..?-1508). En esta estampa los tres personajes son representados como en nuestra escena, con el Niño en el suelo entre ellos, pero María a la derecha y José a la izquierda del espectador, y la mula se atraviesa tras la madre tal como hace en el retablo. En multitud de representaciones la Natividad se inserta en ruinas palaciegas, como ejemplo de que el nacimiento de Cristo viene a edificar un nuevo orden sobre los restos del antiguo.

En una estampa de Alberto Durero de la citada serie La pequeña Pasión vemos una escena de Cristo despidiéndose de su Madre (1504) que podría estar detrás de la composición de nuestra escena con la cananea.

Habitual es la composición de la escena de Tobías y el Ángel que en la pintura italiana había sido representada de forma similar por autores de primera fila como Benozzo Gozzoli (1420-1497), Antonio Pollaiuolo (1429-1498) o Andrea Verrochio (1435-1488), pudiendo en nuestro caso haberse utilizado la estampa con igual motivo realizada en 1527 por Marcantonio Raimondi debido a la semejanza de la vestimenta del arcángel.

La escena de Cristo con la samaritana ${ }^{27}$ está basada en la estampa del mismo tema de la Peregrinación a tierra Santa, con modificaciones o eliminación de elementos secundarios y con la diferencia de que en el libro ella está vertiendo el agua del cubo al cántaro y en nuestra representación está en el momento de sacarla del pozo. Las vestimentas son similares, la ubicación de los personajes, el pozo y el cántaro la misma, cambia el diseño del pozo, añade la estructura que sujeta la garrucha por haber desaparecido el templete que está en el grabado y complica el dibujo de la ciudad que mantiene al fondo a la izquierda, los apóstoles los reduce a dos y los centra en el paisaje. Aunque no se puede saber con certeza cómo eran estos apóstoles, porque apenas quedan unos fragmentos originales. (fig. 5 y 6 )

Se puede citar el parecido que tiene la escena del Santo Job y su mujer con Job en su estiércol, una de las imágenes de las Grandes Horas de Anna de Bretagne (1503-1508) de Jean Bourdichon (1480-1510), aunque es bastante difícil que el autor del Retablo del Salvador pudiera conocer este libro. El fondo arquitectónico con la puerta de la ciudad y la continuación de las murallas y el torreón parece inspirado en Entrada triunfal en Jerusalén (hacia 1509), estampa nuevamente de La pequeña Pasión de Durero.

\footnotetext{
${ }^{27}$ Von Breydenbach, 1486: LXXXIX.
} 


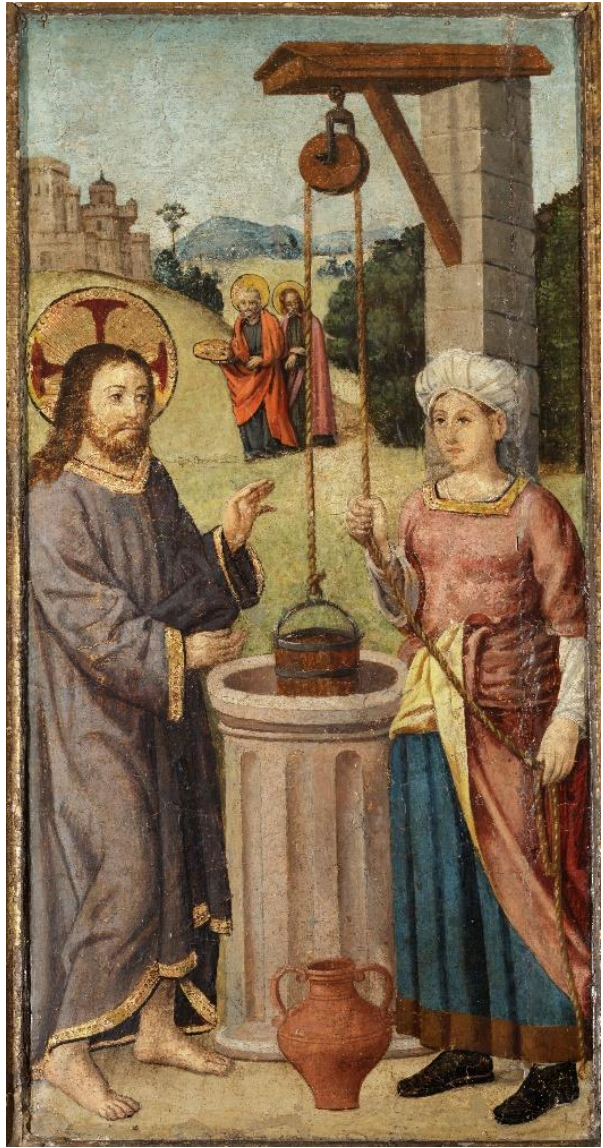

Fig. 5. Anónimo, Retablo del Salvador, mediados del siglo XVI, Museo de Bellas Artes de Sevilla $\left(\mathrm{N}^{\circ} \mathrm{R}^{\circ}\right.$ CE0032P). Detalle con Cristo con la Samaritana.

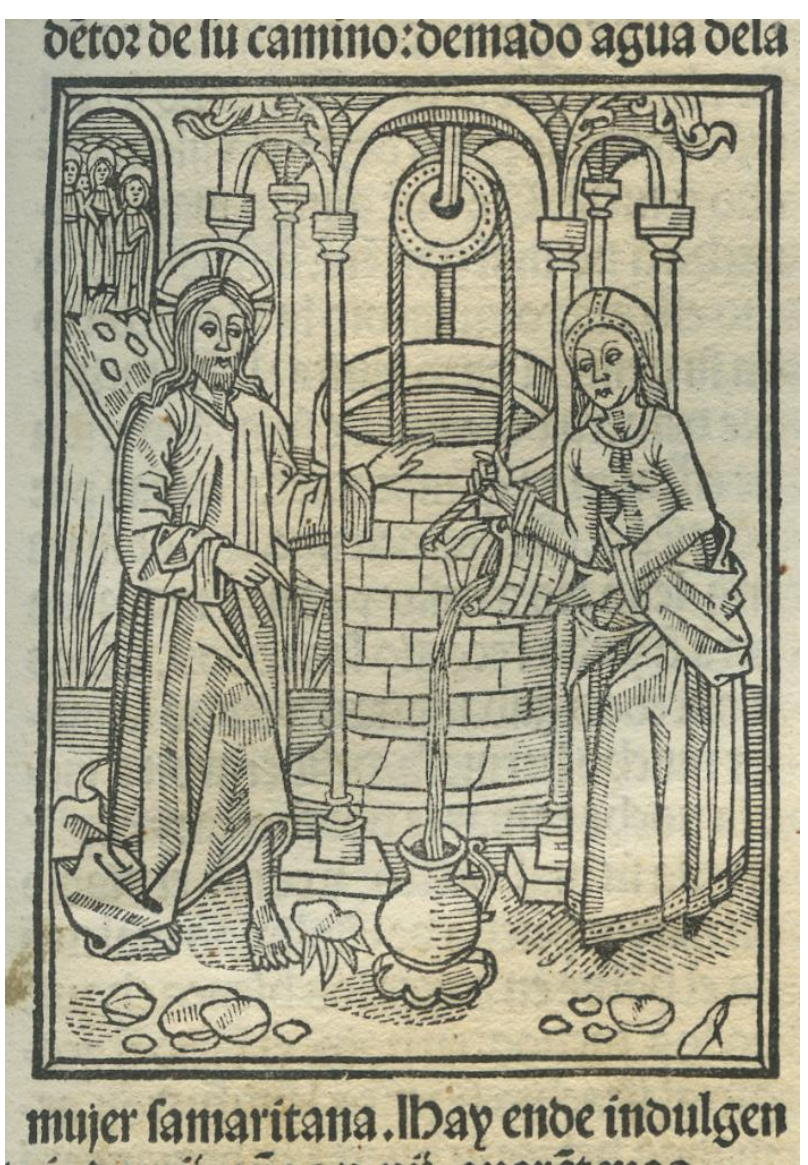

Fig. 6. Von Breydenbach, Peregrinación a Tierra Santa. Imagen de Cristo con la Samaritana, detalle de la página LXXXIX. Biblioteca Complutense. Universidad Complutense, Madrid.

\section{Datos técnicos de la obra Soporte}

El Retablo del Salvador está pintado al óleo sobre tabla en un único soporte. ${ }^{28} \mathrm{Al}$ no haberse realizado análisis en el momento de la redacción de este artículo solamente podemos adelantar que parece ser de madera de castaño, tanto el barrote, como el marco y el soporte. Está realizado con cinco paneles en vertical a unión viva, sujetos con espigas de hierro a media madera introducidas en cajas talladas previamente. En origen tenía cuatro barrotes o travesaños al dorso para evitar deformaciones, situados en sentido contrario a los paneles, fijos desde el anverso por clavos de forja de cabeza redondeada (fig. 7).

Tiene además de los cinco paneles una pieza de unos 17'50 x 7’80 cms. añadida en el borde externo del panel derecho, a poco más del $80 \mathrm{cms}$. del borde superior, situada en el momento de la construcción del soporte por existir un nudo problemático que hubo que resanar, manteniendo otros nudos que no consideraron necesario eliminar. Los diferentes

\footnotetext{
${ }^{28}$ Medidas totales: 218 x 149 cms., y con un grosor que fluctúa entre los 2’3 y los $3 \mathrm{cms}$.
} 


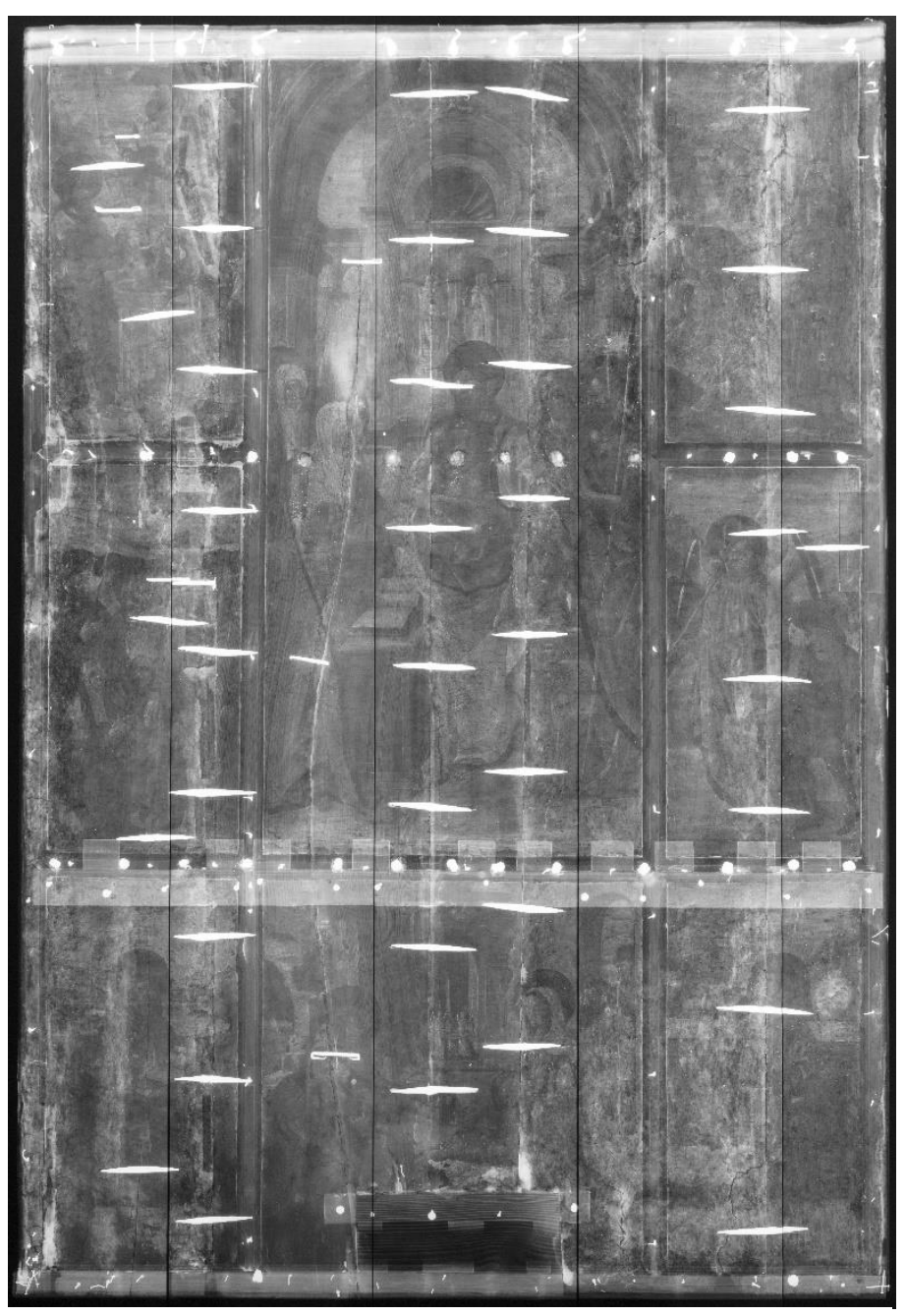

Fig. 7: Anónimo, Retablo del Salvador, Mediados del siglo XVI, Museo de Bellas Artes de Sevilla $\left(\mathrm{N}^{\circ} \mathrm{R}^{\circ}\right.$ CE0032P). Imagen radiográfica. movimientos entre paneles se han marcado en la capa pictórica.

Solamente el barrote superior es original, y está muy fisurado debido a los clavos. Se desconoce el momento en que se eliminaron los otros tres barrotes originales, aunque visto el ataque de insectos xilófagos que ha dañado seriamente el soporte de la obra, posiblemente resultaran inservibles para efectuar su cometido. Los que presentaba al inicio de los tratamientos de conservaciónrestauración, que ha dado origen al presente estudio, debieron añadirse en una intervención efectuada a la obra estando ya en el museo y de la que no se puede precisar fecha, encontrando atornillados dos de ellos desde el reverso, el tercero situado en la zona inferior está clavado desde el anverso utilizando el borde sin pintura que ocupa el marco.

Las cabezas de los clavos que sujetaban en origen los travesaños quedaron cubiertas bajo el enmarcado que separa las diferentes escenas y ha resultado muy eficaz para evitar que se alterara la capa pictórica al oxidarse. Como parece que nunca se ha desclavado el marco, al eliminar tres de los barrotes se limitaron a cortar la mayor parte de cada clavo que sobresalía por el dorso una vez que ya no servían para sujetar los travesaños, sin necesidad de retirarlos por completo. Hacia la mitad de la escena principal, la de Cristo Resucitado, al ser el doble de alta que las escenas aledañas, uno de los barrotes la atravesaba por el dorso, por lo que las cabezas de los clavos se marcaban en la pintura, y por ello, se los sacaron enteros desde el anverso con el daño correspondiente a la zona afectada en la que muy posiblemente pudo ser la primera restauración integral de este retablo realizada en el museo, no toda esa pintura se perdió, pero sin duda sufrió mucho más que si los clavos hubieran permanecido en su lugar de origen o hubiesen sido extraídos por el dorso. De los clavos originales del barrote inferior sólo se conservan dos, habiendo desaparecido los restantes por la falta de madera debido al ataque de insectos xilófagos y a la mutilación sufrida por la tabla que posteriormente se detallará.

Era habitual en la época de realización de este soporte que una vez ensamblado se dejara reposar un tiempo prudencial para que se asentase antes de ser pintado. En ocasiones incluso 
se montaban los retablos en el lugar para el que estaban destinados, y después de adaptados a ese microclima eran trasladados al taller del pintor. ${ }^{29}$ Cuando por movimientos de la madera se producían rajas o fendas, se solían añadir grapas de hierro desde el anverso que posteriormente doblaban para fijarlas al reverso y así impedir que el soporte se siguiera abriendo. Dos de los paneles de este retablo se encuentran rajados en toda su longitud, y se le añadieron grapas, que como es habitual, se han acabado marcando en la superficie pictórica. Con la particularidad de que uno de los paneles a los que se puso estas grapas, el situado a la izquierda, ya se había rajado antes de completado el soporte, según lo evidencia las espigas de sujeción, imposibles de introducir a media madera una vez completada la estructura del soporte sin retirar los barrotes. Hay que añadir que el hierro de estas grapas una vez oxidado dañó la pintura situada sobre ellas, haciendo que se perdiera en gran medida, y así la escena con la Mujer de Canaán tiene reconstruida la cabeza de Cristo en una intervención realizada ya en el museo (comparar fig. 1 y 2).

En la citada fotografía del Archivo Ruiz Vernacci (fig. 2) se aprecia que la parte inferior central de la obra está mutilada, creando un hueco cortado de forma rectangular, de 17 x 35 cms., que pudo hacerse para situar un pequeño sagrario siguiendo las directrices del Concilio de Trento (1545-1563), cuyas reformas ordenaban la inclusión de los sagrarios en los altares de culto aunque no hay certeza al afirmar que éste fuera el motivo más allá de la ubicación y tamaño de esta falta de soporte. Una vez en el museo el hueco se completó con una tabla a medida para recuperar el formato, sujeta por el barrote inferior y otro más pequeño, que atornillado por el reverso fija la tabla añadida en su parte superior. En la unión de esta pieza con el retablo se utilizó cola, yeso y una gran cantidad de estopa y papel que rellena las faltas de soporte original. ${ }^{30}$

Pueden compararse las características del soporte del Retablo con la citada obra de Alejo Fernández, La duda de Santo Tomás ${ }^{31}$ y que posiblemente sirvió a nuestro anónimo pintor de inspiración parcial para componer la escena central como se ha apuntado. Esta obra, que se encuentra en la nave de la Epístola de la parroquia de Hinojos (Huelva). Está realizada en un soporte de seis paneles de madera de pino piñonero (Pinus pinea), corte tangencial, de entre 1'50 y 2'00 cms. de grosor. Presenta el dorso liso, sin las características marcas de herramientas de corte que encontramos en muchos de los soportes de madera, como son la sierra, la hachuela, el formón, etc., acabado que también tiene la obra aquí estudiada. En las uniones de las tablas conserva la muy habitual estopa, adherida con cola y sobre ella una capa de Sulfato cálcico con cola, en un intento de protegerlas y aislarlas. En el Retablo se ha perdido la estopa de las uniones de paneles y solamente quedan restos del yeso.

Este soporte presenta unas diferencias notables con el aquí estudiado, y es que los paneles tienen una unión en $\mathrm{V}$, en lugar de plana y que los travesaños están parcialmente embutidos en el soporte en lo que se denomina media cola de milano, por lo que se pueden deslizar por el mismo, permitiendo el movimiento natural de la madera, a diferencia de los barrotes clavados, que impiden su dilatación y contracción además de los daños causados por el óxido de los clavos.

\footnotetext{
${ }^{29}$ Jover/Alba/Gayo/García-Maíquez, 2015: 214-215.

${ }^{30}$ En la intervención de conservación-restauración que se realiza en el retablo mientras se escribe este artículo se han sustituido los barrotes atornillados y el panel ubicado en la parte inferior.

${ }^{31}$ La Duda de Santo Tomás fue restaurada en el año 2002 por Rocío Campos y María José Robina, a quienes agradezco que me hayan facilitado los datos de la obra y la intervención. Las medidas de esta obra son 190 x $107 \mathrm{~cm}$, aunque posiblemente tenga reducido su tamaño en los laterales.
} 
Sin embargo ambas tablas comparten una característica común, no generalizada en los soportes sevillanos de la época, pues tienen espigas de hierro embutidas a media madera, planas con perfil en forma de huso, y de un tamaño similar.

\section{Capa pictórica}

En tablas del siglo XVI es habitual encontrar tela sobre el soporte lígneo, ésta se situaba como un modo de amortiguar el movimiento de la madera en la capa pictórica que podían producir los cambios de humedad relativa y temperatura, y además esta tela eliminaba las posibles irregularidades del soporte y la que podía provocar la unión de paneles. El efecto era un acabado liso y uniforme, aunque con el tiempo se ha visto que el resultado no siempre ha sido el esperado. ${ }^{32}$

En el anverso del Retablo del museo sevillano se adhirió, cubriendo todo el espacio pintado, una capa de tela de lino tipo tafetán, torsión en Z, con una densidad de $12 \times 12$ hilos por centímetro cuadrado. Este hecho ha podido hacer que hasta nosotros haya llegado capa pictórica que se habría perdido debido a la falta de madera subyacente, desaparecida o debilitada por la tremenda acción de los insectos xilófagos. En este caso la tela ocupa toda la superficie, pero hay obras en las que se encuentran solamente en las uniones de los diferentes paneles, como en la citada La duda de Santo Tomás. En ocasiones se ha creído que algunas obras de esta época por estar pintadas sobre lienzo la madera fue adherida con posterioridad para reforzar el tejido.

Sobre la tela se aplicaron varias capas de yeso y silicatos, con un yeso más grueso y con mayores impurezas en la capa inferior que en la superior, más puro y con una molienda fina y homogénea, ${ }^{33}$ formando una preparación blanca y lisa. Para completar el aparejo y la preparación, sobre este yeso se debía aplicar una capa de cola para evitar el exceso de absorción del aglutinante oleoso de la

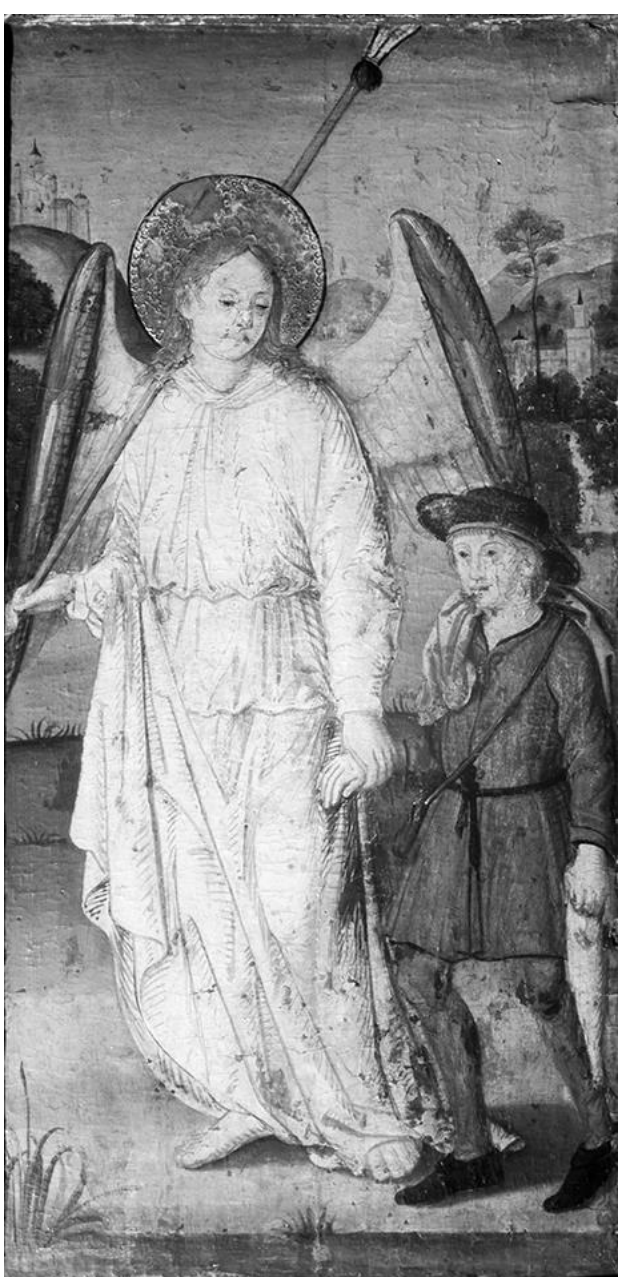

Fig. 8. Anónimo, Retablo del Salvador, Mediados del siglo XVI, Museo de Bellas Artes de Sevilla $\left(\mathrm{N}^{\circ} \mathrm{R}^{\circ}\right.$ CE0032P). Detalle con la imagen de la Reflectografía con infrarrojos de San Rafaely Tobias. pintura. Generalmente, antes de esta capa se realizaba el dibujo preparatorio, como en este caso. Las imágenes conseguidas por la Reflectografía con Infrarrojos (fig. 8) de El retablo del Salvador muestran un rico dibujo subyacente realizado a pincel con tinta o pigmento oscuro. Perfila los márgenes de las figuras

\footnotetext{
${ }^{32}$ Se sabe que en el contrato de 1582 para pintar y dorar el desaparecido retablo de las reliquias de la Catedral de Sevilla se exigía que sobre el soporte de madera se adhiriera una tela previa a la preparación, según cita Gómez Sánchez, 2020: 241.

${ }^{33}$ Los análisis de capa pictórica y tejido han sidp realizados por ARTE LAB (Madrid).
} 
y objetos con líneas largas y precisas, al igual que los plegados de los ropajes. Los rostros tienen muy definida la ubicación de los rasgos, ojos, cejas y ojeras, nariz y boca, el cabello y los pelos de las barbas, e incluso la sombra que pudiera formar la nariz dependiendo de la incidencia de la luz. Los dedos de las manos o los pies son generalmente muy sencillos, pero en ocasiones tienen dibujadas las uñas. Las sombras se señalan con pequeñas líneas paralelas, rectas en su mayoría, pero cuando quieren indicar que en ese lugar se forma un pliegue, ya sea de tela o de piel, encontramos que esas líneas se curvan. No se aprecian arrepentimientos reseñables en la realización final de la obra con respecto al dibujo preparatorio. Debido a la parcial transparencia del óleo, que puede ocurrir con el tiempo, y a los gastados de pintura que presenta esta obra, se aprecia a simple vista parte de este dibujo, que nunca se realizó para ser observado por el espectador.

La citada mutilación del retablo se unió al tremendo daño por el ataque de xilófagos, y a filtraciones de humedad por capilaridad en la zona inferior, haciendo que las escenas representadas en ese espacio tengan grandes faltas de pintura, que incluso han hecho casi desaparecer al Niño Jesús y al buey y la mula de la Natividad, así como más de la mitad inferior del Santo Domingo y algo menos la imagen de San Francisco. Todas las escenas tienen una abundante cantidad de pérdidas.

La pintura del Retablo del Salvador es cubriente, aunque en general nos ha llegado barrida o desgastada. Presenta pinceladas largas en el cielo o los paños, y precisas en los detalles, como en las manos y pies o rostros. Los ropajes alternan pliegues quebrados de tradición gótica con otros de caída más natural, pero que aun así apenas nos muestran las formas corporales de los personajes exceptuando el volumen de alguna pierna adelantada. Utiliza colores sólidos, variados, bien distribuidos en la composición. ${ }^{34}$ El paisaje, realizado a base de lomas azuladas y verde vegetación, recortada en un cielo clásico en degradación de intensidad de azul, y con arquitecturas de inspiración renacentista en la escena central y medievales en los edificios situados en el paisaje con árboles y algunos setos son correctos y enmarcan equilibradamente los personajes. Una coincidencia con casi todos los autores sevillanos de la época es la perspectiva aérea que no se ajusta a estrictos cánones, encontrando diferentes puntos de fuga en los espacios de suelo o elementos arquitectónicos, e inexactas o ausentes las sombras estabimentadas o reflejadas. También se muestra como un pintor de recursos limitados cuando presenta individuos hieráticos, casi inexpresivos, que no trasmiten conexión entre ellos, con manos esquemáticas, planas, a diferencia de los pies, los ojos, boca, etc., todo ello bien dibujado, y con un claroscuro correcto. A pesar de esta rigidez en los personajes, el resultado ofrece escenas claras, luminosas y legibles, con proporción en el tamaño de las figuras aunque en algunas escenas presentan cánones más alargados que en otras. No son representaciones que incluyan detalles pormenorizados, ni en la vegetación, ni en las arquitecturas, ni en los ropajes, pero el mensaje con estos personajes, apenas arropados por elementos distorsionadores, debía llegar fácilmente al fiel.

Utiliza el pan de oro aplicado sobre bol rojo, en las aureolas y en las cenefas de los ropajes, graneado con dibujos sencillos, simulando flores, pétalos o líneas de punzonado o burilado diferentes; utiliza pocos tipos de troquel, como las líneas en las aureolas crucíferas de Cristo, y solamente dos grosores de buril. Las cenefas son similares, y las aureolas de San Pedro y de San José lo son entre sí, siendo algo diferentes a las del resto de personajes que ostentan

\footnotetext{
${ }^{34} \mathrm{El}$ análisis de pigmentos nos muestra que se utilizó para la realización de esta obra albayalde, azurita, cardenillo, bermellón, carbón vegetal o tierras.
} 
aureolas parecidas, destacando sólo la de rayos del Santo Job y las de Cristo. Las únicas aureolas perdidas completamente son las de Santo Domingo, las de los apóstoles que avanzan al fondo de la escena de Cristo con la samaritana y la de Cristo con la cananea.

En la época de realización de esta obra, admitiendo la datación asignada en este texto, el uso del pan de oro en las pinturas estaba en recesión e imprime al Retablo del Salvador un aire arcaizante.

\section{E1 marco}

El enmarcado es del tipo superpuesto o postizo, acanalado, con una medida de unos 4'30 cms. de ancho, clavado al soporte desde el frente, pudiendo verse por el dorso alguno de los clavos que lo atraviesan. Este enmarcado separa todas las escenas, y tiene ensambles a inglete en el cruce de listones. La medida de la moldura situada en el borde exterior es algo más ancha, hasta 5'00 cms., porque añade una meseta o canto pintada de color verde, mientras que el resto, entrecalle convexa y filo, ha sido terminado con pan de oro, dorado al agua, sobre bol rojo. El dorado y la pintura se han perdido en gran medida. Los listones tienen el largo de cada escena, y para amortiguar las uniones, sobre los ingletes, se adhirió un trozo de tela de lino, no a toda la superficie como en el resto de la obra. Este lienzo no impidió los desniveles en la unión de los diferentes largueros por movimientos de la madera del soporte. El marco se clavó previo a aplicar la preparación a la obra y su posterior dorado y pintado como puede verse en la intersección de las escenas al mismo. Al ser del tipo superpuesto no cubre los cantos de la tabla, lo que hace pensar que este retablo pudo estar encajado en un espacio en el muro de su capilla, por lo que no hizo falta disimular la visión de la madera sin decorar. En los cantos laterales, cortados en chaflán en disminución de delante hacia atrás, se encuentran agujeros dejados por los clavos que lo fijarían al muro, habiendo conservado solamente un fragmento de uno de estos clavos introducido en la madera.

Al cortar el trozo central de la parte inferior, ya citado como posible hueco para situar un sagrario, no solo se perdió capa pictórica sino que también fue eliminada esa zona del marco, como se observa en la fotografía de hacia 1870 , así como la zona inferior del derecho debido a otros daños y resanado en una restauración posterior, eliminándose todo el inferior y un trozo más del derecho, que fue sustituido por un listón copia del original, pintado con imitación a oro, hoy alterado de color.

Este marco es similar al que podemos encontrar en otras obras del momento, como por ejemplo el del Santo Entierro ${ }^{35}$ (1525), de Cristóbal de Morales (activo en Sevilla en la primera mitad del siglo XVI). Esta pintura también tiene tela completa sobre el soporte de madera e igualmente fue añadida la preparación una vez clavado el marco. Es un marco muy alejado de los retablos góticos con guardapolvo y cresterías y de los grandes retablos renacentistas con columnas y frontones. ${ }^{36}$

\section{Otras obras relacionadas con el Retablo del Salvador: San Telmo}

Post cita en su A History of Spanish Painting ${ }^{37}$ : "Affiliations with the retable in manner setting are manifested by a lone panel on the same Museum that displays the strange Spanish

\footnotetext{
${ }^{35}$ Cristóbal de Morales, Santo Entierro. Óleo sobre tabla, medidas: 176’50 x 123’50 cms. Museo de Bellas Artes de Sevilla. Número de Registro: CE0048P. Obra restaurada por María Dolores Fúster en el año 1991. Posiblemente, al igual que en esta obra de Morales, el basamento del marco del retablo que estudiamos estuviera realizado en talud o vierteaguas.

36 Timón, 2010: 166-180.

${ }^{37}$ Post, 1970: 283- 284.
} 
saint, Telmo [...] but the evidence is far from adequate for the assertion of a single authorship". A partir de esta relación entre El retablo del Salvador y San Telmo ${ }^{38}$ parece factible la conexión entre ambas obras tras haberlas observado con otra mirada.

San Telmo (fig. 9) debió pertenecer a un retablo de procedencia desconocida. En el marco dice que estuvo originalmente en una ermita, pero está mutilado en sus cuatro bordes y el enmarcado es posterior. La similitud de los soportes de las dos obras del Museo de Bellas Artes de Sevilla, nos lleva a la hipótesis de estar realizados por el mismo carpintero, lo que no significa necesariamente que luego las pintara el mismo artista.

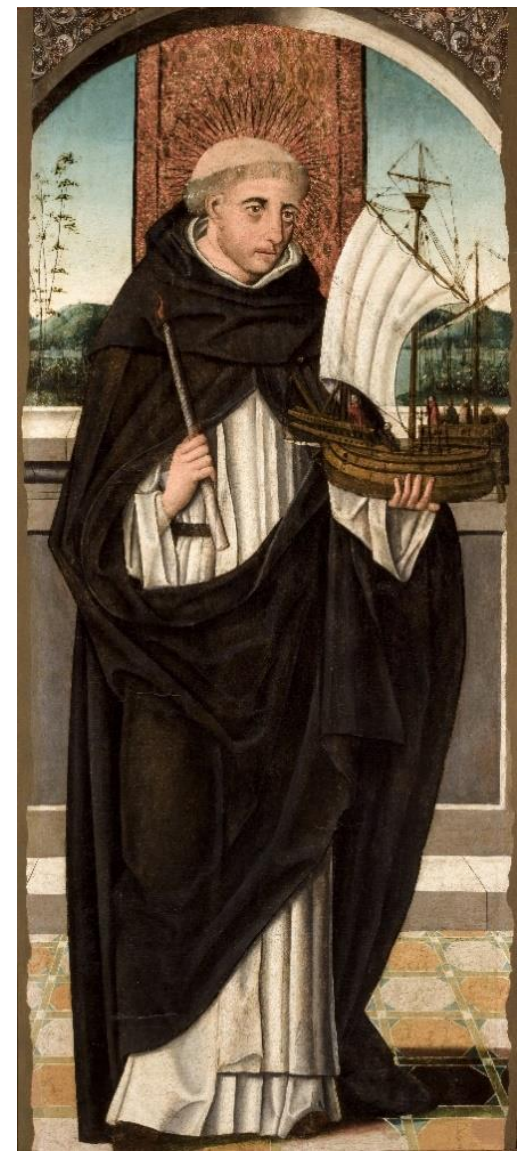

Fig. 9. Anónimo, San Telmo, Primera mitad del siglo XVI, Museo de Bellas Artes de Sevilla $\left(\mathrm{N}^{\circ}\right.$ $\left.\mathrm{R}^{\mathrm{o}} \mathrm{DO} 0038 \mathrm{P}\right)$.

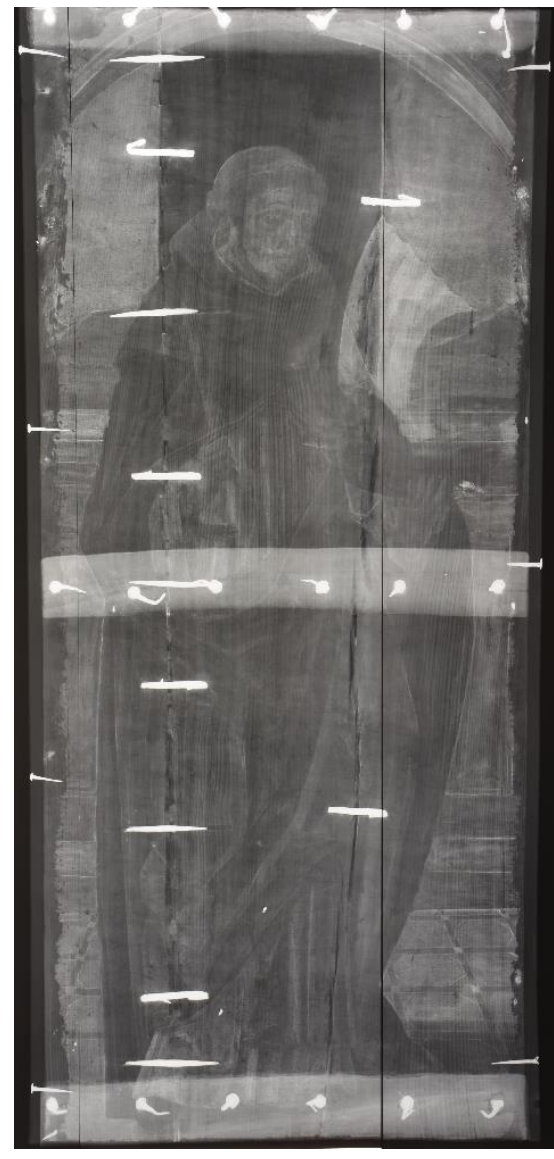

Fig. 10. Anónimo, San Telmo, Primera mitad del siglo XVI, Museo de Bellas Artes de Sevilla $\left(\mathrm{N}^{\circ}\right.$ $\left.\mathrm{R}^{\mathrm{o}} \mathrm{DO} 0038 \mathrm{P}\right)$.

Ya se ha indicado que San Telmo está mutilado en todo su perímetro, pero mantiene los barrotes originales y tiene un estado de conservación bastante bueno, mostrando incluso al dorso la marca del maderero, aún se puede ver la estopa y yeso de protección de las juntas de los paneles. Tanto los barrotes como el soporte creemos que son de madera de castaño. Los barrotes están clavados desde la cara de la pintura, y hay espigas de hierro embutidas a media madera tal como lo habíamos visto en el Retablo, aunque aquí son algo más pequeñas,

\footnotetext{
${ }^{38}$ Anónimo sevillano (siglo XVI), San Telmo. Museo de Bellas Artes de Sevilla. Número de Registro: DO0038P. Medidas: 128’5 x 56 cms. Restaurado por Mercedes Vega Toro en el año 1995.
} 
los clavos y las espigas son similares, aunque de diferente tamaño (fig. 10) ${ }^{39}$ Las dos obras estudiadas se habían rajado y añadido grapas idénticas previamente a ser preparada la madera para ser pintada. Posteriormente, a ambas se les adhirió una tela de lino tipo tafetán que eliminara las deformaciones del soporte antes de añadir la preparación, sobre la que luego se realizó el dibujo previo.

Como se ha indicado, al redactar este texto aún no se ha analizado el tipo de madera del Retablo del Salvador ni del San Telmo, aunque sí se realizó a éste último un estudio de Fluorescencia de Rayos X. ${ }^{40}$ Lo que sí hay es la imagen del dibujo subyacente conseguido con la Reflectografía con infrarrojos. ${ }^{41}$ Ambas obras presentan el mismo tipo de realización, materia acuosa oscura aplicada con pincel, y tipo de trazo que enmarca los perfiles y con pequeñas líneas para el sombreado o curvatura de paños y miembros del representado. Si a esto se añade que el modo de pintar los diferentes elementos y la aplicación de las pinceladas es muy similar, se puede llegar a la conclusión de que las dos obras son del mismo autor.

Comparando el San Telmo pintado por Alejo Fernández conservado en el Real Alcázar de Sevilla formando parte del retablo de la Virgen de los Navegantes (1531-1536), vimos que no coinciden en elementos compositivos, como los paños o el paisaje. La relación, aparte de la cercanía en el tiempo y ciudad de realización, se basa solamente en la iconografía, ya que el representado lleva en la mano los mismos símbolos, el barco y el cirio, y lógicamente se viste con los hábitos de la orden dominica. Al igual que se vio en la representación de Santo Domingo y San Francisco del Retablo del Salvador, esta figura está situada en una galería abierta, sobre un suelo de mármol en damero, en este caso más rico en diseño, delante de un pretil de piedra y con un paisaje al fondo, que incluye aquí una masa de agua que podría ser un río al estar rodeada de montes. La gran diferencia en la representación entre esta imagen y el santo Domingo y el san Francisco del Retablo es el paño que lo enmarca a su espalda, realizado en damasco dorado con un dibujo de red fusiforme que se entrecruza, decorado con pequeñas rosetas insertadas en las intersecciones, a lo que se añade una cenefa en los laterales formada también por flores, aquí con largos tallos y hojas a lo largo, realizado con graneado, todo ello en pan de oro sobre bol rojo. Y por último, señalar que la cabeza de San

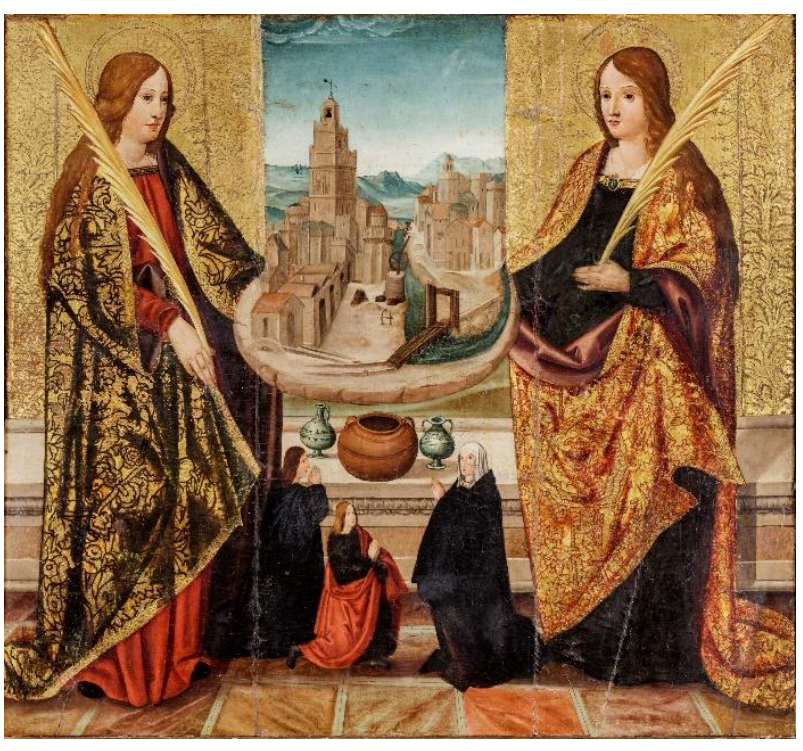

Fig. 11: Anónimo, Retablo de Santa Justa y Rufina y Adoración de los Reyes, principios del siglo XVI. Parroquia de Santa Ana, Triana (Sevilla). Detalle con Santa justa y Rufina.

\footnotetext{
${ }^{39}$ Las radiografías están realizadas por Pedro Feria, la del Retablo del Salvador en 2018, y la del San Telmo en 2019.

${ }^{40}$ La Fluorescencia de Rayos X de San Telmo fue realizada por Anabelle Kriznar y Kilian Laclavetine en el año 2012, Los resultados de este estudio nos da coincidencias con los pigmentos utilizados en el Retablo, como son el albayalde, la azurita o el bermellón, pigmento que por otra parte eran utilizados de manera generalizada por los pintores de la época.

${ }^{41}$ Las Reflectografías del San Telmo las realizó Anabelle Kriznar y Kilian Laclavetine 2012. Las Reflectografías del Retablo del Salvador las realizó Pepe Morón en 2015 y 2018.
} 
Temo aparece rodeada de rayos que surgen de la misma al igual que la representación del Santo Job del Retablo en lugar de la habitual aureola redonda. ${ }^{42}$

\section{Santas Justa y Rufina y Adoración de los Reyes}

En relación con las dos obras anteriores parece oportuno comparar además una tabla que se conserva en la Parroquia de Santa Ana de Triana, Sevilla, Santas Justa y Rufina y Adoración de los Reyes, (fig. 11) citada tradicionalmente como atribuida al Maestro de Moguer. Su falta de relación con maneras de hacer de Fernández, como sí muestran las tres pinturas que en origen dan nombre a ese desconocido maestro, el hieratismo, la inexpresión, la manera de diseñar los rostros, las manos, la forma de aplicar las pinceladas, la monumentalidad de los personajes, el diseño del suelo, los sillares, el pretil con un borde de talla vegetal, como en el San Telmo, además de la relación con Sevilla, como sin duda muestran las otras obras aquí estudiadas, nos plantea la posibilidad de una misma autoría, aunque el análisis de la misma no lo confirma. Sobre todo porque es muy diferente el dibujo subyacente encontrado en la tabla de Santa Justa y Rufina y Adoración de los Reyes. Está realizado de una manera mucho más sencilla que en las dos obras anteriormente estudiadas, delimitando las figuras sin marcar las sombras, y en este caso no parece que se empleara pincel, sino pluma (fig. 12). Hubiera sido interesante estudiar el soporte lígneo de esta pintura, que a diferencia de las otras obras, parece mostrar en el anverso grapas uniendo los diferentes paneles, no las fendas, indicando que posiblemente

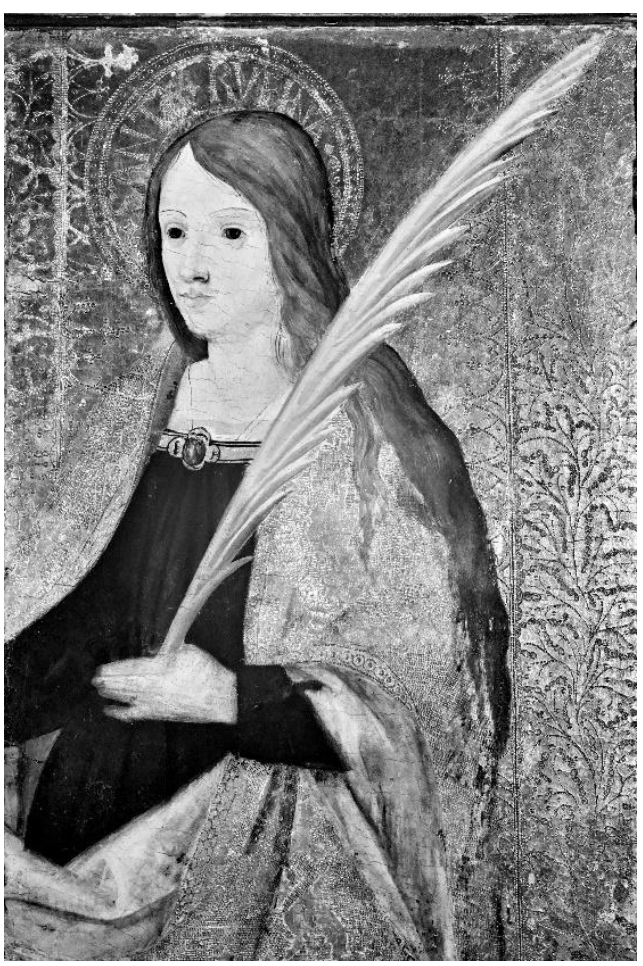

Fig. 12. Anónimo, Retablo de Santa Justa y Santa Rufina y Adoración de los Reyes, Principios del Siglo XVI, Parroquia de Santa Ana, Triana (Sevilla). Detalle con la imagen de la Reflectografía con infrarrojos de Santa Rufina. Paco Morón, 2019. no tendrá espigas, es decir, diferente a las otras dos pinturas estudiadas. Ambas escenas están de igual manera realizadas en un solo soporte con barrotes clavados desde el anverso. En esta doble obra la utilización del oro es mucho más abundante, más rica la variedad de graneado, y la representación de los nombres en las aureolas, como en el caso de las santas, deriva de épocas anteriores, al igual que la representación de tejidos adamascados con rosetas y piñas que llevan los personajes principales. Debido a ésto se puede aventurar que esta tabla es anterior a las dos aquí estudiadas, e incluso que San Telmo puede serlo también con respecto al Retablo del Salvador.

La Adoración de los Reyes está claramente inspirada en la estampa que representa la Adoración de los magos (1470) de Martín Schongauer (1445-1491).

Los recursos utilizados en cada momento y lugar eran similares en casi todos los artistas, al menos los que se habían preparado en talleres locales y seguían de una manera cercana las

${ }^{42}$ Tradicionalmente las aureolas radiales se asignaban a los beatos. En 1254 san Telmo fue beatificado por el Papa Inocencio IV, y en 1741 se reafirmó como tal por el Papa Benedicto XIV. No ha sido canonizado. 
ordenanzas gremiales. Esto sirve en ocasiones para comprobar la técnica coincidente de soportes o capa pictórica y asignar obras a un mismo entorno artístico, aunque siempre será el estilo de cada artista el que nos indique la autoría común de obras sin documentar. Se puede considerar que las pinturas del museo sevillano tienen suficientes semejanzas de realización como para pensar afirmativamente que han salido de los mismos carpintero y artista, sin embargo, la de la Parroquia de Santa Ana presenta un soporte que no parece estar realizado de igual manera, y sobre todo se diferencia en el dibujo subyacente, por lo que no es oportuno afirmar una misma autoría, a pesar de las semejanzas estilísticas finales con las de la pinacoteca hispalense. En lo que respecta a la relación de la obra de Triana con las desaparecidas procedentes de Moguer, no vemos coincidencias.

El conocimiento que puede transmitir una obra durante su tratamiento de conservaciónrestauración es amplio y muy variado pudiendo ayudarnos a relacionar de diferente manera las piezas tratadas, aunque en gran parte de las ocasiones no tiene divulgación. Desde la dendrocronología a la composición de los barnices, pasando por los tejidos, las preparaciones, dibujo subyacente, dorados o corladuras, pigmentos y aglutinantes, el análisis de una escultura o una pintura puede ser rico y variado y completar su estudio. Los talleres de restauración atesoran un conocimiento poco utilizado por una parte de los historiadores del arte. 


\section{Bibliografía}

Ávila, Ana (1993): Imágenes y simbolos en la arquitectura pintada española (1470-1560). Barcelona: Ed. Anthropos.

Campos Alvear, Rocío. Robina Ramírez, Mª José. Ravé Prieto, Juan Luis (2002): Memoria de la Conservación-Restauración de la tabla: La duda de Santo Tomás. (Inédita).

Gestoso y Pérez, José (1912): Catálogo de las Pinturas y Esculturas del Museo Provincial de Sevilla. Madrid: Imp. De J. Lacoste.

Gómez Imaz, M. (1917): Inventario de los cuadros sustraidos por el gobierno intruso en Sevilla (año 1810). Sevilla.

Gómez Sánchez, Juan Antonio (2020): “Costosíssimo y muy de ver” El retablo de las reliquias de la Catedral de Sevilla, 1559-1584. Diputación de Sevilla.

Gómez Sánchez, Juan Antonio (2016): Alejo Fernándezy la pintura sevillana del primer tercio del siglo XVI. (Tesis Docoral inédita). Universidad de Sevilla, Sevilla. http://hdl.hande.net/11441/39210. [Consultado 24 de enero de 2020]

Jover, Maite/Alba, Laura/Gayo, María Dolores/García-Máiquez, Jaime (2015): “El taller del pintor: Procedimientos artísticos en el obrador de Luis de Morales" pp 213-225. El Divino Morales. Madrid: Museo Nacional del Prado.

Moreno Mendoza, Arsenio/Pareja López, Enrique/Sanz Serrano, María Jesús/Valdivieso González, Enrique (1991): Museo de Bellas Artes de Sevilla. Sevilla: Ediciones GEVER, S. L.

Ponz, Antonio (1947): Viaje de España. Seguido de los dos tomos del Viaje fuera de España. Madrid: M. Aguilar Editor.

Post, Chandler Rathfon (1950): The Early Renaissance in Andalusia (A History of Spanish Painting, vol X). Cambridge (Massachuttsets): Harvard University Press.

SOTHEBY PARKE BERNET \& CO. SUCURSAL EN ESPAÑA (1979): Catálogo de la subasta de El Quexigal. La casa y su contenido. Del 25 al 27 de Mayo 1979. Madrid.

Timón, María Pía (2010): “Tipología de los marcos españoles en los Siglos XV y XVI” pp 166-180. La pintura europea sobre tabla. Siglos XV, XVI y XVII. Madrid: Ministerio de Cultura. Secretaría General Técnica. Subdirección General de Publicaciones, Información y Documentación.

Tormo y Monzó, Elías (1911): Catálogo de las tablas de primitivos españoles de la colección de la Excma. Señora Doña Trinidad Schotz-Hermensdorff, Viuda de Iturbe. Madrid.

Von Breydenbach, Bernhard (1498): Peregrinación a Tierra Santa. Zaragoza: Pablo Hurus. 